\title{
My reflections on abortion law reform
}

\section{Rachel D'Souza}

Consultant in Sexual and Reproductive Health, Margaret Pyke Centre, London, UK

\section{Correspondence to} Dr Rachel D'Souza, Margaret Pyke Centre, Mortimer Market Centre, Capper Street, off Tottenham Court Road, London WC1E 6JB, UK; rachel.d'souza@nhs.net

Received 29 November 2016 Accepted 29 November 2016

\section{CrossMark}

To cite: D'Souza R. J Fam Plann Reprod Health Care 2017;43:72-74.

\section{BACKGROUND}

We all bring our personal views to our practice, as this journal's new section, 'Person in Practice', highlights. ${ }^{1}$ My position on abortion is challenging to hold as a consultant in sexual and reproductive health (SRH) and I have spent much time reflecting on this. The following is an edited transcript of a talk I was invited to give at a recent meeting convened by the Faculty of Sexual and Reproductive Healthcare at which abortion law reform was being considered.

\section{ABORTION LAW AND REGULATION}

One of the main purposes of the law is to protect the concerns and interests of the community as a whole, especially its vulnerable members. We have laws which protect newborn babies against abuse and maltreatment, and animals from being neglected or tortured in our own homes. We have laws governing the way animals are used in research. Similarly, we are concerned about the rights and interests of fetuses. The law against procuring an abortion except under the terms of the 1967 Abortion Act reflects these concerns.

We are also, as a community, concerned about the rights and interests of a woman who is pregnant but doesn't want to be, respecting her desire to abort her pregnancy, often for intensely personal and understandable reasons. It is important to acknowledge these, as well as the fact that women who choose to discontinue their pregnancy will use whatever means it takes to procure an abortion, even, if necessary, in ways that are unsafe. Surveys carried out by the Guttmacher Institute ${ }^{2}$ suggest that worldwide levels of abortion are more strongly linked to the incidence of unintended pregnancy than to the legal status of abortion, and that high abortion rates are directly correlated to high levels of unmet contraceptive need, often in countries where abortion is highly restricted.
In England, Wales and Scotland today, abortion is effectively available on demand up to 24 weeks. So, contrary to the claims of the British Pregnancy Advisory Service's current 'We Trust Women' campaign for decriminalisation of abortion in the UK, ${ }^{3}$ a woman's 'fundamental rights' are not denied. A woman who uses abortion medication at home is unlikely to be sent to prison for life, as this campaign suggests: breaking the law is not automatically followed by criminal proceedings, but is subject to discretionary interpretation, as also occurs in cases of assisted suicide for compassionate reasons.

We do need protection, though, against the situation that, however unlikely, an individual chooses to perform abortions illegally for financial gain. The 1861 Offences Against the Person Act reflects our concern about the interests and protection of fetuses right up to the moment of birth. We do not tolerate fetal loss due to assault during pregnancy, and it is important that the law balances the concern of the community to protect the fetus, with the rights and beliefs of the woman who has a pregnancy she does not wish to continue.

We are increasingly aware of life in utero. Documentaries show high definition images of fetal development and document the incredible survival of many premature babies. In fact, most photo albums now start with an in utero image. And whilst a recent British Social Attitudes survey ${ }^{4}$ found that $62 \%$ support abortion on a woman's request, I do not think that public opinion generally supports pregnancies being allowed to be terminated up to birth.

Along with many others in our community, I believe each of us is created special and unique. This means I choose not to stop a pregnancy once it has implanted - the point at which a potentially viable pregnancy becomes established. My objection is not because I am 
fearful of any consequences, but because I am in awe of the new creation developing in the womb. Others who choose not to perform abortions rarely make this decision purely because of concern of prosecution. So, I do not agree with the 'We Trust Women' campaign $^{3}$ that an abortion should be regulated like any other healthcare procedure such as a hernia repair.

\section{WOMEN'S CHOICES}

This does not mean I judge others for the choices they make. Statistically one in three women will have an abortion at some time in their life, and women with an unwanted pregnancy often face a difficult choice whatever they decide. We should support women in making this choice. We should offer additional support to those with an unwanted pregnancy who are more likely to experience regret and psychological sequelae in the future - routinely screening for possible coercion, exploring ambivalence, giving space to the individual woman's religious or moral views, and carefully considering any mental health issues.

I realise that by far the majority of clinicians working within women's health do not relish performing abortions, and work hard to improve access to and uptake of effective contraception to reduce the incidence of abortions, and repeat abortions. I also am passionate about this, both in the UK and beyond - it is what has motivated me to choose and continue a career in SRH.

Yet a minority of women uses abortion as a form of contraception, even where this is free and accessible, for complex reasons. Ann Furedi, in her book The Moral Case for Abortion, ${ }^{5}$ suggests that a woman should be able to choose to practise birth control through abortion instead of contraception given that the clinical risks of an early abortion are not significantly higher than those of contraception. In addressing this, we might look to the Netherlands, where society places a high value on contraceptive use among sexually active people, and unintended pregnancy is rare. I am particularly saddened when encountering young women trying to get pregnant just to check their fertility but with no plan to continue with the pregnancy.

\section{TIME LIMITS}

Is life of such little value? Babies born as early as 22 weeks' gestation now sometimes survive, albeit with neonatal intensive care. It seems inconsistent to allow abortion beyond the stage when the fetus would have a chance of surviving outside the womb. Except in extreme circumstances, such as risk to the life of the mother - in which case the baby could be delivered prematurely and given a chance to survive.

I realise that fetal viability is an arbitrary cut-off. But as survival becomes possible at earlier gestations we should be lowering the 24-week abortion time limit, contrary to the recommendation by the "We
Trust Women' campaign ${ }^{3}$ to remove it entirely. How different is a 33-week premature baby in the neonatal unit to a 33-week fetus that we give so much protection and value to one, yet consider aborting the other? In her book, ${ }^{5}$ Furedi gives the example of a woman who has conceived a wanted pregnancy but after the man she once thought loved her has left her, decides she no longer wants to continue the pregnancy. Sadly, this could happen at any time in her pregnancy, and beyond, and is not a good reason for removing the abortion time limit.

\section{FETAL DEFECTS AND DISABILITY}

And just as abortion, in my opinion, should not occur once the fetus is viable, this should equally be the case where there is a fetal abnormality except where this is incompatible with life. What does it say to those in our society who have a disability if we choose to end the life of a fetus because it has a defect? We are living in a contradictory society, where on the one hand we strive to eliminate discrimination and on the other, strive to prevent the birth of babies with disabilities, discriminating against them at their most vulnerable stage. I am not at all suggesting that it is easy to raise a child with a disability, and don't judge people for making the choice to abort such fetuses, but believe society needs to draw some protective lines. Is a cleft palate really a significant disability enough to justify abortion?

The 'Don't Screen Us Out' campaign ${ }^{6}$ picks up on this, concentrating on pregnancies affected by Down's syndrome and the availability of a non-invasive prenatal DNA test. They are pressing for improvements in how parents receive a diagnosis of Down's syndrome, particularly for more balanced communication without pressure to abort; and better support to be able to choose the option of having their baby.

\section{CONCLUDING REMARKS}

As a Christian, and as a clinician who has worked within SRH for nearly 20 years, acknowledging the complexity of the issue and respecting women's views and wishes, I believe the law needs to continue to balance protection of the fetus with protection for the rights and interests of the woman who has an unwanted pregnancy. I support retaining, even reducing the time limit for abortion, including abortion for fetal disability. We must ensure that there is adequate support for a woman to make a choice that she believes is best for her, unpressurised by partner, parents, clinicians or the expectations of society - often difficult in a busy abortion clinic. And that we continue to push for effective contraception to be the norm for those sexually active and not wishing to be pregnant, including campaigning for better Sex and Relationships Education in schools. My hope is not for abortion to be illegal, rather to make it rare, because society places a high value on avoiding unwanted pregnancy. 
Competing interests None declared.

Provenance and peer review Commissioned; internally peer reviewed.

\section{REFERENCES}

1 Berger A. Venting grief for vocational erosion. J Fam Plann Reprod Health Care 2016;42:297.

2 Sedgh G, Bearak J, Singh S, et al. Abortion incidence between 1990 and 2014: global, regional, and subregional levels and trends. Lancet 2016;388:258-267.
3 British Pregnancy Advisory Service. 'We Trust Women' campaign. http://www.wetrustwomen.org.uk/ [accessed 23 November 2016].

4 British Social Attitudes Survey. Personal Relationships: Abortion. NatCen Social Research, 30th edition. 2015. http://www.bsa. natcen.ac.uk/latest-report/british-social-attitudes-30/personalrelationships/abortion.aspx [accessed 23 November 2016].

5 Furedi A. The Moral Case for Abortion. London, UK: Palgrave Macmillan, 2016.

6 'Don't Screen Us Out' campaign. http://dontscreenusout.org/ [accessed 23 November 2016]. 